Atmos. Chem. Phys., 10, 7231-7239, 2010

www.atmos-chem-phys.net/10/7231/2010/

doi:10.5194/acp-10-7231-2010

(C) Author(s) 2010. CC Attribution 3.0 License.

\title{
First ground-based FTIR observations of methane in the inner tropics over several years
}

\author{
A. K. Petersen ${ }^{1,2}$, T. Warneke ${ }^{1}$, C. Frankenberg ${ }^{3}$, P. Bergamaschi ${ }^{4}$, C. Gerbig ${ }^{5}$, J. Notholt ${ }^{1}$, M. Buchwitz ${ }^{1}$, \\ O. Schneising ${ }^{1}$, and O. Schrems ${ }^{6}$ \\ ${ }^{1}$ Institute of Environmental Physics, University of Bremen, Bremen, Germany \\ ${ }^{2}$ Max-Planck Institute for Meteorology, Hamburg, Germany \\ ${ }^{3}$ SRON Netherlands Institute for Space Research, Utrecht, The Netherlands \\ ${ }^{4}$ Institute for Environment and Sustainability (IES), European Commission Joint Research Centre, Ispra, Italy \\ ${ }^{5}$ Max-Planck Institute for Biogeochemistry, Jena, Germany \\ ${ }^{6}$ Alfred Wegener Institute for Polar and Marine Research, Bremerhaven, Germany
}

Received: 4 January 2010 - Published in Atmos. Chem. Phys. Discuss.: 1 February 2010

Revised: 29 July 2010 - Accepted: 3 August 2010 - Published: 6 August 2010

\begin{abstract}
Total column concentrations of methane have been retrieved from ground-based solar absorption FTIR spectra in the near-infrared recorded in Paramaribo (Suriname). The methane FTIR observations are compared with TM5 model simulations and satellite observations from SCIAMACHY, and represent the first validation of SCIAMACHY retrievals in the inner tropics using ground-based remote sensing techniques. Apart from local biomass burning features, our methane FTIR observations agree well with TM5 model simulations. The comparison of the direct measured $\mathrm{CH}_{4} / \mathrm{CO}_{2}$ ratios by FTIR and satellite reveals that the satellite can hardly detect methane emissions of tropical biomass burning due to the used retrieval method.
\end{abstract}

\section{Introduction}

Methane $\left(\mathrm{CH}_{4}\right)$ is the second most important anthropogenic greenhouse gas in the atmosphere and is one of the target gases of the Kyoto protocol. Its global atmospheric concentration has more than doubled since preindustrial times and reached 1774 ppb in 2005 (IPCC: Forster et al., 2007). Very recently, surface measurements from global monitoring networks revealed a renewed growth of atmospheric methane in

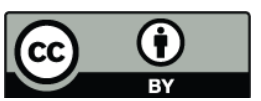

Correspondence to: A. K. Petersen

(katinka.petersen@zmaw.de)
2007 and 2008 on a global scale (Rigby et al., 2008; Dlugokencky et al., 2009a). This change in the growth rate is not yet understood and reveals the importance of measurements and research on the global methane budget.

Sources and sinks of atmospheric methane are not yet well quantified. In particular, in the tropics a large uncertainty in the methane budget exists due to the scarcity of measurements (e.g. Meirink et al., 2008b). The lack of observations is mostly due to the inaccessibility of the tropical forests, as well as the lower priorities given to this region in the past. Ground-based solar absorption FTIR measurements of methane have been reported for Mauna Loa, Hawaii $\left(19.5^{\circ} \mathrm{N}, 155.6^{\circ} \mathrm{W}\right)$ during February 1987 (Rinsland et al., $1988)$ and at Ile de La Réunion $\left(21^{\circ} \mathrm{S}, 55^{\circ} \mathrm{E}\right)$ during two measurement campaigns in 2002 and 2004 (Senten et al., 2008). Both sites are located in the outer regions of the tropics. Before 2004, there have been no FTIR observations in the inner tropics. The only site in the inner tropics is the Paramaribo site. The Paramaribo observatory fills in an important gap in the global atmospheric observation network, which is essential for global change research and assessment. Earth observation satellites that have been or will be launched in the near future can partly compensate for the lack of observations in the tropics. However, there is a growing need for surface observations for the validation and calibration of these satellite instruments.

Published by Copernicus Publications on behalf of the European Geosciences Union. 
Space-borne measurements for total column $\mathrm{CH}_{4}$ have become available from the Scanning Imaging Absorption Spectrometer for Atmospheric Cartography (SCIAMACHY) instrument onboard ENVISAT, with an estimated relative accuracy on the order of 1-2\% (Frankenberg et al., 2005, 2006; Buchwitz et al., 2006; Schneising et al., 2009). However, due to the complexity of the retrieval algorithms and the limited availability of independent measurements for validation, the quantification of potential systematic retrieval errors remains very difficult. Recently, Frankenberg et al. (2008a) reported a major revision of their $\mathrm{CH}_{4}$ retrievals, mainly a consequence of the identification of systematic errors in the spectroscopic parameters of $\mathrm{CH}_{4}$ (Frankenberg et al., 2008b) and $\mathrm{H}_{2} \mathrm{O}$ vapor (Frankenberg et al., 2008a). This revision resulted in significantly lower column-averaged $\mathrm{CH}_{4}$ mixing ratios, especially in the tropics. The systematic retrieval errors were caused by spectroscopic errors and interference between $\mathrm{H}_{2} \mathrm{O}$ and $\mathrm{CH}_{4}$, and were most pronounced in the tropical regions, where $\mathrm{H}_{2} \mathrm{O}$ vapour is most abundant. Inversions based on the revised SCIAMACHY retrievals using the TM5 four-dimensional variational (TM5-4DVAR) inverse modeling system yield $\sim 20 \%$ lower tropical emissions compared to the previous retrievals (Frankenberg et al., 2008a; Bergamaschi et al., 2009). In this paper, we present the first inner tropical ground-based FTIR measurements of methane. These observations are used for validation of the SCIAMACHY methane retrievals. For this purpose, we compare our ground-based observations over several years with the two existing SCIAMACHY methane retrievals, the WFM-DOAS (Weighting Function Modified DOAS, Buchwitz et al., 2006) and the IMAP-DOAS (Iterative Maximum A Posteriori-DOAS, Frankenberg et al., 2005) retrieval. Furthermore, we compare the simulations of the TM5-4DVAR model with our ground-based FTIR observations as well as with surface in situ measurements of $\mathrm{CH}_{4}$.

\section{Site description and retrieval}

The FTIR measurements were performed at the Meteorological Service in Paramaribo, Suriname $\left(5.8^{\circ} \mathrm{N}, 55.2^{\circ} \mathrm{W}\right)$ during seven consecutive dry seasons between September 2004 and November 2007. Campaigns during short dry seasons (SDS, February to March) are denoted as SDS campaigns, while campaigns during long dry seasons (LDS, August to November) as LDS campaigns. The Intertropical Convergence Zone migrates twice a year over the measurement site. During the SDS, Paramaribo belongs to the meteorological Northern Hemisphere, and during the LDS, it belongs to the meteorological Southern Hemisphere (Fortuin et al., 2007).

The retrieval of trace gas concentrations from absorption spectra is based on the comparison of measured with simulated spectra. For an a priori state of the atmosphere (e.g. pressure and temperature profiles) and taking into account instrumental influences, a transmission spectrum of the atmo- sphere is calculated. Through variation of certain parameters (e.g. trace gas concentrations) in the simulation, the calculated spectrum is fitted to the measured spectrum. Total column trace gas concentrations can be retrieved by scaling the trace gas concentration profiles during the fit.

In addition to the retrieval of total column amount, for some trace gases it is possible to retrieve information about the vertical distribution from the analysis of the shape of absorption lines, e.g. by optimal estimation. The spectral line shape of an absorption line is influenced by the natural line width, Doppler broadening and pressure broadening. Since pressure decreases with height, pressure broadening dominates in the troposphere whereas in the stratosphere, Doppler broadening is dominant in the infrared. Information about the volume mixing ratio profiles can be gained as high up as pressure broadening is dominant. The retrieval of methane total column amounts in the near-infrared (NIR) spectral region by profile scaling has been used successfully in a number of cases (Warneke et al., 2006; Washenfelder et al., 2003), showing good agreement with model simulations and surface observations.

Solar absorption spectra, recorded with a Bruker $120 \mathrm{M}$ FTIR spectrometer were analysed using the SFIT2 vs2.92 algorithm (Spectral Least Square Fitting Program) developed at NASA Langley Research Center and the National Institute for Water and Atmospheric Research in New Zealand based on optimal estimation (for further details see Rinsland et al., 1998) to retrieve volume mixing ratios and total column amounts of methane. The FTIR solar absorption spectra were analysed in the same spectroscopic regions and with the same spectroscopic linelists as used for the $\mathrm{CH}_{4}$ IMAP-DOAS retrieval from low-resolution spectra from SCIAMACHY (Frankenberg et al., 2008a). The a priori profiles used for the FTIR retrievals are based on the a priori profiles used for tropical sites within the TCCON network (http://www.tccon.caltech.edu/). Profiles of pressure, temperature and relative humidity are obtained from the NOAA Climate Diagnostics Center (CDC) based on NCEP (National Centers for Environmental Prediction) Reanalysis data (http://www.cdc.noaa.gov/data/gridded/data. ncep.reanalysis.html). Methane total columns are retrieved from FTIR spectra in the spectral window from 5995 to $6115 \mathrm{~cm}^{-1}$. The interfering species $\mathrm{CO}_{2}$ and $\mathrm{H}_{2} \mathrm{O}$ are also fitted in the same microwindow.

At the tropical site Paramaribo, the methane total column retrieval by profile scaling showed strong sensitivity to the a priori information as well as to different microwindows used for the retrieval, which we ascribe to too unrealistic a priori information for the tropical trace gases, water interference, a too restricted retrieval algorithm due to profile scaling only retrieval (no freedom to adjust the shape of the profiles) or other unknown effects. Due to its specific location within the migration zone of the ITCZ, at the Paramaribo site air masses belonging to the northern (SDS) as well as to the Southern Hemisphere (LDS) are observed by the FTIR. The use of a 

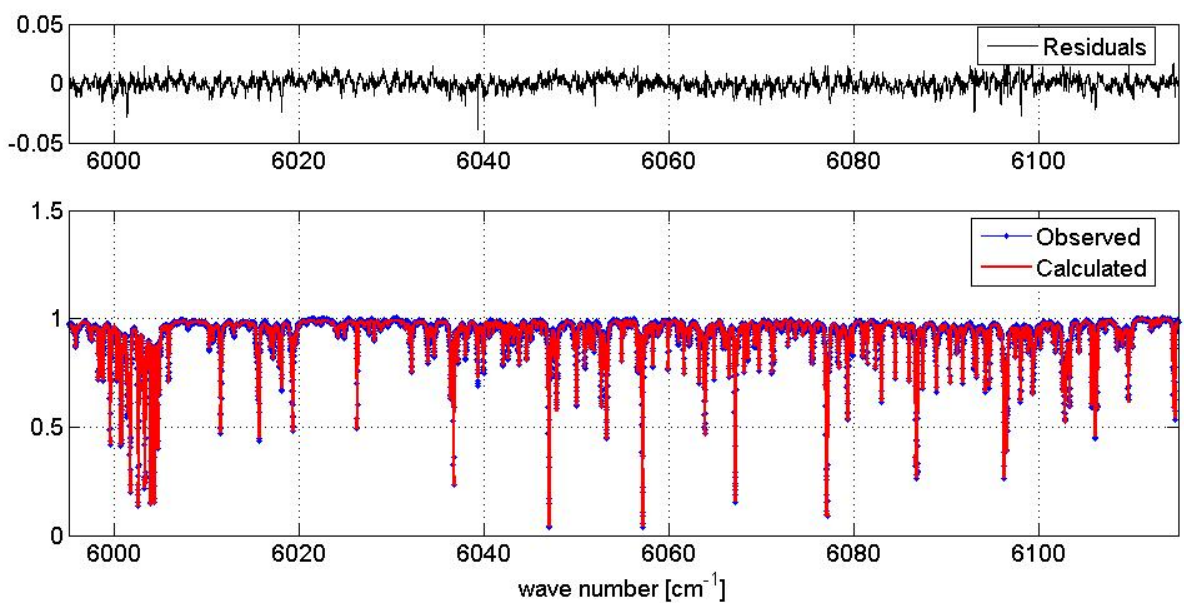

Fig. 1. Spectral microwindow used for the retrieval of methane from FTIR spectra in Paramaribo. The upper panel shows the residuals (difference between the measured and the fitted spectrum, in absolute values), indicating that the measured spectrum is well fitted. The channeling visible in the residuals is caused by an infrasil glass filter used in the instrument in Paramaribo. This is not influencing the results.

single a priori profile for the profile scaling only retrieval may be too restrictive for a trace gas like methane having very different concentrations and profiles in both hemispheres. On the other hand, the use of two different a priori profiles for the SDS campaigns and LDS campaigns respectively may introduce unreal seasonality by the a priori. In order to solve the problem of reduced freedom due to profile scaling only, we used the SFIT2 algorithm for profile retrieval based on optimal estimation. Volume mixing ratios and total column amounts of methane have been derived from NIR spectra with SFIT2 by fitting a whole transition band instead of single absorption lines, as commonly applied for the retrieval of trace gas profiles in the mid-infrared (MIR). The spectral window used is one order of magnitude larger than commonly used for the profile retrieval (see Fig. 1). Since a whole transition band (consisting of several absorption lines with different temperature sensitivities) is used for the retrieval, inconsistencies of spectroscopic parameters for certain absorption lines and assumed a priori information for the pressure-temperature profiles have less impact on the results.

Total columns of carbon dioxide are retrieved from the same NIR spectra as methane (microwindow: 6180$6260 \mathrm{~cm}^{-1}$ ) by profile scaling (see Fig. 1). The retrieved total column amounts are converted to column averaged volume mixing ratios (XVMR) by dividing the retrieved vertical column by the total dry air column:

$\mathrm{XVMR}\left(\mathrm{CH}_{4}\right)=\frac{\operatorname{column}\left(\mathrm{CH}_{4}\right)}{\text { total dry air column }}$,

where the total dry air column is

total dry air column $=\frac{P_{\mathrm{obs}}}{m_{\mathrm{dry}} g(\varphi)}-\operatorname{column}\left(\mathrm{H}_{2} \mathrm{O}\right)\left(\frac{m_{\mathrm{H}_{2} \mathrm{O}}}{m_{\mathrm{dry}}}\right)$.
$P_{\text {obs }}$ denotes the observed surface pressure, $m_{\text {dry }}$ the mean molar mass of dry air $\left(0.028964 \mathrm{~kg} \mathrm{~mol}^{-1}\right), m_{\mathrm{H}_{2} \mathrm{O}}$ the mean molar mass of water vapour $\left(0.01802 \mathrm{~kg} \mathrm{~mol}^{-1}\right)$ and $g(\varphi)$ is the latitude dependent surface acceleration due to gravity. We estimate the error on the $\mathrm{CH}_{4} \mathrm{XVMR}$ to be less than $0.2 \%$ for a pressure uncertainty of $2 \mathrm{hPa}$, which we assume to be the maximal error for the pressure measurements during all campaigns. The potential errors in the FTIR observations due to errors in the pressure measurements are negligible compared to the diurnal variations. The diurnal variation of the methane observations can be used as a measure for the precision of the observations (Warneke et al., 2006). Part of the diurnal variation of $\mathrm{CH}_{4}$ will be caused by real variations in $\mathrm{CH}_{4}$ over the day, therefore this method given an upper limit for the precision.

\section{Comparison with space-borne measurements}

Methane retrievals from SCIAMACHY are performed in a microwindow in channel 6, ranging from 5983 to $6138 \mathrm{~cm}^{-1}$ $(1629-1671 \mathrm{~nm})$. The SCIAMACHY retrievals used within this work are described in detail by Frankenberg et al. (2008a) for the IMAP-DOAS v50, and by Schneising et al. (2009) for the WFM-DOAS v1.0 retrieval algorithm. The SCIAMACHY products represent the measured total column of $\mathrm{CH}_{4}$ normalized to the measured total column of $\mathrm{CO}_{2}$. The measured columns of $\mathrm{CH}_{4}$ and $\mathrm{CO}_{2}$ are derived from neighboring spectral regions, ensuring very similar light path distributions for both species. The column averaged $\mathrm{CH}_{4}$ mixing ratio $\mathrm{XVMR}\left(\mathrm{CH}_{4}\right)$ is obtained by 
$\operatorname{XVMR}\left(\mathrm{CH}_{4}\right)=\frac{\text { meas. column }\left(\mathrm{CH}_{4}\right)}{\text { meas. column }\left(\mathrm{CO}_{2}\right)} \cdot \mathrm{XVMR}$ model $\left(\mathrm{CO}_{2}\right)$

using modeled column averaged mixing ratios of $\mathrm{CO}_{2}$ $\left(\mathrm{XVMR}_{\text {model }}\left(\mathrm{CO}_{2}\right)\right)$. Global spatio-temporal $\mathrm{CO}_{2}$ concentration fields have been calculated by the atmospheric tracer transport model TM3 driven with re-analysed meteorological data (NCEP) (Rödenbeck, 2005). Surface $\mathrm{CO}_{2}$ fluxes supplied to the model comprise detailed representations of fossil fuel emissions, land biosphere exchange, and oceanic exchange, as well as a large-scale inversely calculated correction flux ensuring consistency with measured atmospheric $\mathrm{CO}_{2}$ concentrations at many sites around the globe. Details about the model are described by (Rödenbeck, 2005), and data are available online (http://www.bgc-jena.mpg.de/ $\sim$ christian.roedenbeck/download-CO2-3D/). For the IMAPDOAS v50 retrieval, a priori methane fields are applied using the TM5-4DVAR model at $180^{\circ} \mathrm{W}$ at the same days and latitudes; for the WFM-DOAS v1.0, a single (constant) vertical methane profile is used. Due to the relatively high single measurement noise of satellite retrievals, we use a \pm 15 days running average of the daily means of the satellite observations over $4.0-8.0^{\circ} \mathrm{N}, 54.0-57.0^{\circ} \mathrm{W}$ containing both land and ocean pixels. The 15 days running average of the daily means (IMAP-DOAS: blue line, WFM-DOAS: red line) is shown in Fig. 2 together with the standard deviations of the daily means.

Apart from the first part of LDS 2004 and the LDS 2005, the FTIR observations of methane at Paramaribo are in general in good agreement with the satellite observations retrieved with different algorithms within the limitations of the satellite data quality (see Fig. 2). The WFM-DOAS v1.0 retrievals, available only for 2003 to 2005 , use a single (constant) methane a priori and show less temporal variation at this location than the IMAP-DOAS v50, using a priori methane fields of the TM5-4DVAR model fields, which seems to be the major reason for this temporal variation. During the first part of LDS 2004 and during the whole LDS 2005, the FTIR observations are higher than the \pm 15 day running average of SCIAMACHY (see also Tables 2 and 3). From FTIR observations of carbon monoxide (CO) and other biomass burning related trace gases, model simulations and trajectory analysis it is known that Paramaribo experienced air masses polluted by biomass burning during this time (for details see Petersen et al., 2008). During the whole LDS 2005 campaign, CO levels were enhanced by $12 \pm 2.5 \%$ compared to other campaigns. We observed CO levels of $2.3 \times 10^{18} \mathrm{molec} / \mathrm{cm}^{2}$ with peaks of up to $3.5 \times 10^{18} \mathrm{molec} / \mathrm{cm}^{2}$. These enhancements are clearly caused by emissions from fires on the South American continent confirmed by back-trajectory analysis and fire counts from satellite measurements (see electronic supplement of Petersen et al., 2008). Statistics on the fire counts during the LDS 2004 and 2005 give no evidence for enhanced biomass

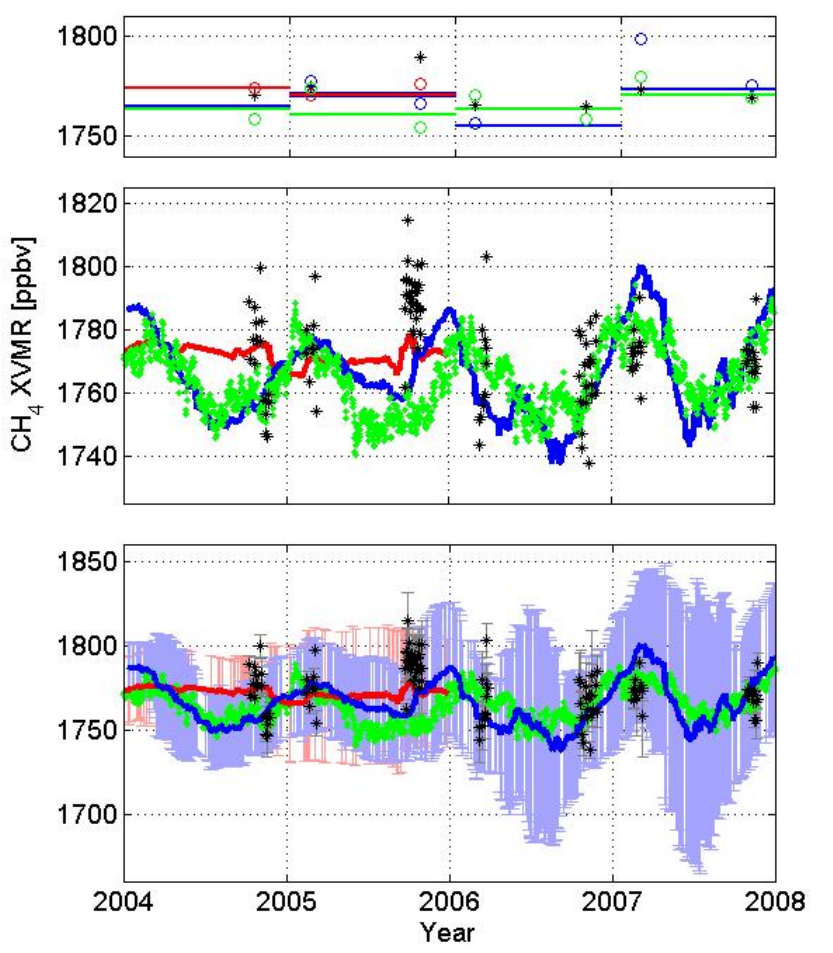

Fig. 2. Retrieved $\mathrm{XVMR}\left(\mathrm{CH}_{4}\right)$ from FTIR (black stars) and SCIAMACHY spectra (IMAP-DOAS in blue, WFM-DOAS in red) averaged over $4.0-8.0^{\circ} \mathrm{N}, 54.0-57.0^{\circ} \mathrm{W}$ compared with daily values of TM5 model simulations assimilated with NOAA surface observations (green). In the lower most panel the 15-days running average over daily means from SCIAMACHY retrievals (lines) and the standard deviations of the daily means (error bars) are shown. Due to the degradations of channel 6 of the SCIAMACHY instrument, larger standard deviations are observed in 2006 and 2007. The FTIR observations are daily means (black stars) with standard deviations. The panel in the middle shows the same as the lower most panel, but without the error bars. The IMAP-DOAS retrieval is scaled with 1.01. TM3 model data for $\mathrm{CO}_{2}$ is used to derive the $\mathrm{XVMR}\left(\mathrm{CH}_{4}\right)$ in the SCIAMACHY retrievals. The upper most panel shows the annual means of the daily means of the satellite observations and the TM5 model, as well as the means of the daily values of the satellite observations (IMAP-DOAS in blue, WFM-DOAS in red), the TM5 model (green) and the FTIR observations (black) for each measurement campaign (averages are only over days when FTIR observations have been performed). The annual means and means over each campaign are given in Tables 2 and 3.

burning during the LDS 2005, neither in Africa nor in South America. However, back-trajectories indicate that during the LDS of 2005, a higher percentage of air masses are coming from South America compared to the same season in the years 2004 and 2006, so that greater levels of regional biomass burning pollution are experienced (Petersen et al., 2008). 
Table 1. Emission factors (EF) for biomass burning tropical forest (Andreae and Merlet, 2001).

\begin{tabular}{lcc}
\hline & $\begin{array}{c}\text { EF in gram species } \\
\text { per kilogram dry } \\
\text { matter burned }\end{array}$ & $\begin{array}{c}\text { EF in mol species } \\
\text { per kilogram } \\
\text { dry matter burned }\end{array}$ \\
\hline $\mathrm{CH}_{4}$ & $6.8 \pm 2.0$ & $0.42 \pm 0.13$ \\
$\mathrm{CO}_{2}$ & $1580 \pm 90$ & $35.9 \pm 2.1$ \\
$\mathrm{CO}$ & $104 \pm 20$ & $3.71 \pm 0.71$ \\
\hline
\end{tabular}

Using typical emission factors of $\mathrm{CO}$ and $\mathrm{CH}_{4}$ from biomass burning of tropical forest (see Table 1), we can estimate the enhancement of $\mathrm{CH}_{4}$ relative to background levels emitted from biomass burning (for details, see the electronic supplement).

$$
\begin{aligned}
\left(\mathrm{CH}_{4}\right)_{\mathrm{BB}} & =\frac{\mathrm{EF}\left(\mathrm{CH}_{4}\right)}{\mathrm{EF}(\mathrm{CO})} \cdot(\mathrm{CO})_{\mathrm{BB}} \\
& =\frac{6.8}{104}\left(\frac{\left[\mathrm{g} \mathrm{CH}_{4}\right]}{\left[\mathrm{g} \mathrm{CO}^{-1}\right.}\right)^{-1} \cdot(\mathrm{CO})_{\mathrm{BB}} \\
& =\frac{6.8}{104}\left(\frac{16.04 \mathrm{~g} \mathrm{~mol}^{-1}}{28.01 \mathrm{~g} \mathrm{~mol}^{-1}}\right)^{-1} \cdot(\mathrm{CO})_{\mathrm{BB}} \\
& =0.114 \cdot(\mathrm{CO})_{\mathrm{BB}}
\end{aligned}
$$

From the observed CO levels during the LDS 2005, we expect 0.3 to $1.7 \times 10^{17} \mathrm{molec} / \mathrm{cm}^{2}$ of additional methane from biomass burning assuming tropical forest emission factors (for details, see the electronic supplement). This is equivalent of around 0.1 to $0.5 \%$ ( 2 to $9 \mathrm{ppb}$ ).

Our calculations can only confirm part of the observed methane enhancement. The reason can be deviations of the used emission factors from the true ones, or the much shorter lifetime of $\mathrm{CO}$ compared to methane: from back trajectory analysis we know, that the observed $\mathrm{CO}$ was transported to Suriname from the South American continent, mostly from Brazil (Petersen et al., 2008). Due to a shorter lifetime of CO compared to $\mathrm{CH}_{4}$, it is possible, that we observe less $\mathrm{CO}$ but still higher methane from the biomass burning source. The significance of the lifetime and transport can be estimated: assuming a lifetime of 1 month for $\mathrm{CO}$, after 5 days, only $85 \%$ of the $\mathrm{CO}$ is left. Assuming a lifetime of 10 years for $\mathrm{CH}_{4}$, less than $1 \%$ is gone in the 5 days.

The enhanced $\mathrm{CH}_{4}$ observed by the FTIR during the LDS 2005 cannot be seen in the SCIAMACHY XVMR observations because of the large footprint of the SCIAMACHY retrievals and the retrieval method itself. Column averaged volume mixing ratios are derived from the measured ratio $\mathrm{CH}_{4} / \mathrm{CO}_{2}$. Methane enhancements due to biomass burning are hidden in the $\mathrm{CH}_{4} / \mathrm{CO}_{2}$ ratio as both species are enhanced in a similar way given typical emission factors by Andreae

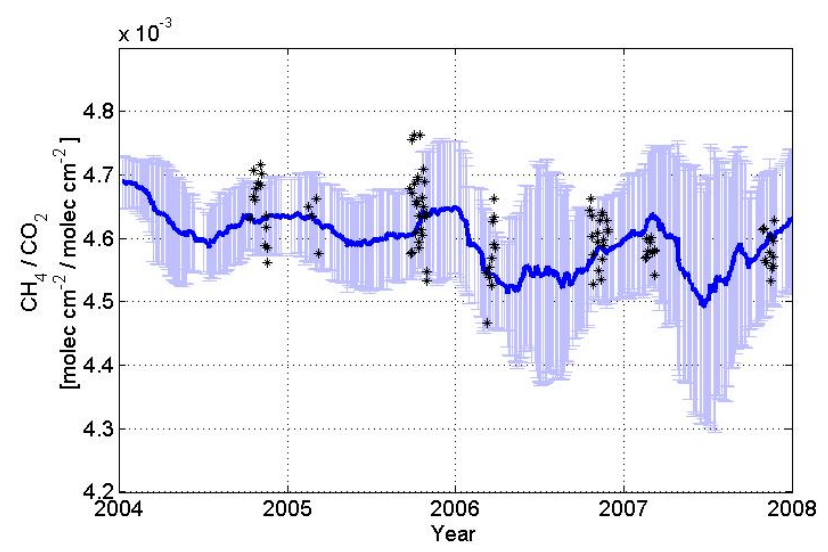

Fig. 3. Ratio of the total columns of $\mathrm{CH}_{4}$ and $\mathrm{CO}_{2}$ retrieved from FTIR and SCIAMACHY (IMAP-DOAS) spectra averaged over $4.0-8.0^{\circ} \mathrm{N}, 54.0-57.0^{\circ} \mathrm{W}$. Shown is the 15 -days running average over daily means from SCIAMACHY IMAP-DOAS retrieval (blue line) and the standard deviations. Due to the degradations of channel 6 of the SCIAMACHY instrument, larger standard deviations are observed in 2006 and 2007.

and Merlet (2001) (see electronic supplement). Furthermore, model assumptions may introduce biases when unrealistic $\mathrm{CO}_{2}$ model data are used. The comparison of the directly measured ratio of $\mathrm{CH}_{4} / \mathrm{CO}_{2}$ from both instruments allows the ground-based validation of the satellite retrieval without further model assumption. The directly measured $\mathrm{CH}_{4} / \mathrm{CO}_{2}$ ratios retrieved from FTIR spectra are in good agreement with the SCIAMACHY observations (Fig. 3).

The direct comparison of the measured species allows the validation of the measurements itself, but also shows the limitations of the satellite retrieval methods. Both retrieval methods for SCIAMACHY XVMR $\left(\mathrm{CH}_{4}\right)$ are not well suited for the detection of biomass burning, because the methane emissions due to tropical biomass burning are hidden in the $\mathrm{CH}_{4} / \mathrm{CO}_{2}$ ratio as both species are enhanced in a similar way (see electronic supplement). The good agreement of the $\mathrm{CH}_{4} / \mathrm{CO}_{2}$ ratio of FTIR and satellite, and the differences between FTIR and satellite XVMR $\left(\mathrm{CH}_{4}\right)$ shows that the influence of biomass burning for methane can hardly be detected by the satellite (with this retrieval method). It is important to know how the retrieval method is done and to be careful with conclusions from the satellite observations. The consistency of the FTIR and the satellite observations of the $\mathrm{CH}_{4} / \mathrm{CO}_{2}$ ratio suggests that biomass burning might be the cause for the differences observed between the FTIR and the SCIAMACHY XVMR $\left(\mathrm{CH}_{4}\right)$.

\section{Comparison with model simulations}

In the following we compare our observations with 3-D model fields assimilated with the TM5 four-dimensional variational (4D-VAR) data assimilation system. Essential 
Table 2. Yearly means of the methane XVMR with standard deviations (note: for the satellite retrievals, the mean is an average over the running means and the standard deviation is the deviation of the running means relative to the yearly mean).

\begin{tabular}{cccr}
\hline & $\begin{array}{c}\text { TM5 } \\
{[\mathrm{ppbv}]}\end{array}$ & $\begin{array}{c}\text { IMAP DOAS } \\
{[\mathrm{ppbv}]}\end{array}$ & $\begin{array}{r}\text { WFM DOAS } \\
{[\mathrm{ppbv}]}\end{array}$ \\
\hline 2004 & $1764 \pm 8$ & $1765 \pm 26$ & $1774 \pm 21$ \\
2005 & $1761 \pm 11$ & $1770 \pm 32$ & $1771 \pm 38$ \\
2006 & $1764 \pm 10$ & $1755 \pm 45$ & \\
2007 & $1771 \pm 10$ & $1773 \pm 58$ & \\
\hline
\end{tabular}

parts of the TM5-4DVAR system are described in detail in (Meirink et al., 2008b) and subsequent further improvements in (Bergamaschi et al., 2009). We use here global coarse resolution $\left(6^{\circ} \times 4^{\circ}\right)$ simulations, interpolated to the coordinates of the Paramaribo site. Surface observations of methane, taken from the NOAA ESRL global cooperative air sampling network (Dlugokencky et al., 1994, 2003), have been used to optimize the two-dimensional distribution of surface emissions. Only measurements from marine and continental background sites have been used for the inversion.

Daily mean values from the TM5 model are compared with the daily averaged FTIR observations (Fig. 2 and Tables 2 and 3). During the first part of the LDS 2004 and during the LDS 2005, when Paramaribo experienced air masses polluted by biomass burning, the FTIR observations exceed the model simulations by far. Using $\mathrm{CO}$ as a tracer for biomass burning, we identify biomass burning as a source for the enhanced $\mathrm{CH}_{4}$ levels (see Sect. 2). Apart from these biomass burning events, the FTIR $\mathrm{CH}_{4}$ retrievals are in general in good agreement with the model output. The FTIR data show higher variation than the model representing methane background levels and being on a rather coarse resolution. As reported recently by Rigby et al. (2008) and Dlugokencky et al. (2009a), global surface in situ measurements show enhanced methane levels in 2007 compared to earlier years. The TM5 model based on assimilation of NOAA surface observations shows this anomaly being $\approx 10 \mathrm{ppb}$ higher in 2007 than in the years before (see Fig. 2 and Tables 2 and 3). Apart from the biomass burning periods, the FTIR observations are in good agreement with the TM5 model (see Fig. 2 and Table 3), especially during the SDS and LDS 2007, when the TM5 model shows the methane enhancement compared to the years before. So as far as the precision of the observations allows any conclusions, the ground-based methane total column FTIR observations do not seem to contradict the observations of Rigby et al. (2008) and Dlugokencky et al. (2009a).

Surface samples were taken in Paramaribo and analysed by the MPI Jena by gas chromatography (Fig. 4). The results of the flask measurements in Paramaribo show in general a very high variation, indicating the strong influence of
Table 3. Means of the methane XVMR for each campaign (note: for the satellite retrievals, the mean is an average over the running means, and the standard deviation is the deviation of the running means relative to the yearly mean).

\begin{tabular}{ccccc}
\hline & $\begin{array}{c}\text { FTIR } \\
\text { [ppbv] }\end{array}$ & $\begin{array}{c}\text { TM5 } \\
\text { [ppbv] }\end{array}$ & $\begin{array}{c}\text { IMAP-DOAS } \\
\text { [ppbv] }\end{array}$ & $\begin{array}{c}\text { WFM-DOAS } \\
{[\mathrm{ppbv}]}\end{array}$ \\
\hline LDS 2004 & $1770 \pm 15$ & $1759 \pm 6$ & $1759 \pm 3$ & $1774 \pm 1$ \\
SDS 2005 & $1774 \pm 13$ & $1774 \pm 3$ & $1777 \pm 0$ & $1771 \pm 1$ \\
LDS 2005 & $1790 \pm 10$ & $1754 \pm 4$ & $1766 \pm 6$ & $1776 \pm 2$ \\
SDS 2006 & $1766 \pm 17$ & $1770 \pm 2$ & $1757 \pm 0$ & \\
LDS 2006 & $1765 \pm 14$ & $1759 \pm 6$ & $1759 \pm 4$ & \\
SDS 2007 & $1773 \pm 8$ & $1779 \pm 4$ & $1798 \pm 3$ & \\
LDS 2007 & $1769 \pm 9$ & $1769 \pm 5$ & $1776 \pm 4$ & \\
\hline
\end{tabular}

local and regional sources. Assuming that the lower values are representative for air with small local pollution, it can be concluded that there is a good agreement of the "clean air" flasks with the TM5 model. We assume that the high methane pollution events are due to urban pollution from the city Paramaribo or local and regional biomass burning. The good agreement also in 2007 of the TM5 model with the "clean air" surface in situ measurements as well as with our FTIR observations is consistent with the observations reported by Rigby et al. (2008) and Dlugokencky et al. (2009a). Also shown in Fig. 4 are the surface in situ observations from the NOAA ESRL network at Ascension Island $\left(6^{\circ} \mathrm{N}\right)$ and Ragged Point, Barbados $\left(13^{\circ} \mathrm{N}\right)$ (Dlugokencky et al., 2009b), being the closest NOAA ESRL sampling sites to Paramaribo. The surface observations and the TM5 surface model data in Paramaribo is similar to the observations in Barbados, while the observations in Ascension Island are much lower than in Paramaribo, as expected due to its far more south location. The observations in Barbados are slightly higher during the LDS periods than the TM5 model in Paramaribo. This might be due to its more northern location, while Paramaribo during these periods belongs to the meteorological Southern Hemisphere (see Section Site description and Retrieval).

\section{Conclusions}

From FTIR CO observations in Paramaribo it is known that during the first part of the LDS 2004 and during the whole LDS 2005 air masses above Paramaribo were highly influenced by regional biomass burning pollution (Petersen et al., 2008). During these biomass burning periods, we observe enhanced methane levels with the ground-based FTIR solar absorption measurements. Apart from these biomass burning events, the TM5 model simulations reproduce the FTIR observations. The FTIR measurements, being more sensitive to local influences, show higher variations than the low resolution model. Surface in situ observations performed in Paramaribo show in general a very high variation, indicating 


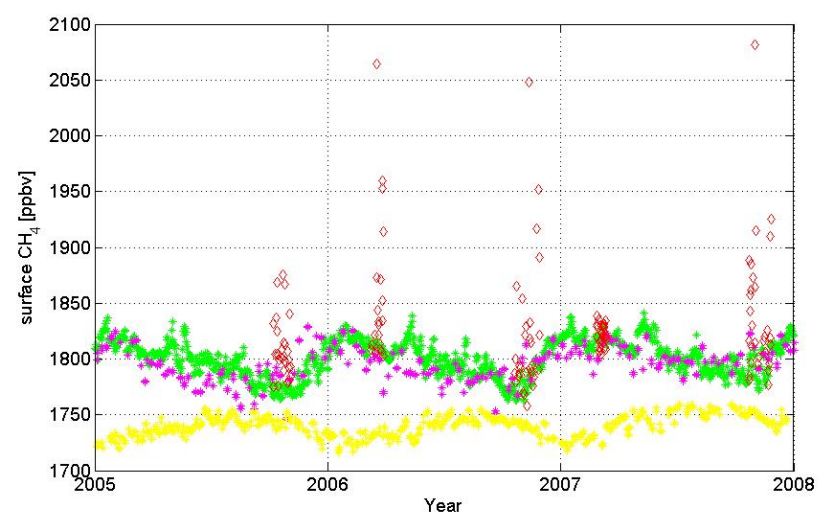

Fig. 4. Methane surface volume mixing ratios from TM5 model simulations, assimilated with NOAA surface observations (green) compared with in situ air samples taken in Paramaribo (red diamonds). Also shown are the closest in situ observations from the NOAA network at Ascension Island $\left(6^{\circ} \mathrm{S}\right.$, yellow) and Ragged Point, Barbados (13 N, magenta) (Dlugokencky et al., 2009b).

the high influence of local and regional sources. However, the lower values of the surface observations, representing the "clean air" observations, agree well with the TM5 model simulations for all campaigns. The TM5 model based on assimilation of NOAA surface observations shows the methane anomaly of 2007, first reported by Rigby et al. (2008). The agreement of the TM5 model with the in situ and the groundbased total column FTIR observations of methane do not seem to contradict the findings of Rigby et al. (2008) and Dlugokencky et al. (2009a), but the precision of the observations does not allow further conclusions. The FTIR observations of methane at Paramaribo agree with the SCIAMACHY observations retrieved with the IMAP-DOAS algorithm within the standard deviation of the daily means apart from the enhancements observed by the FTIR during the LDS in 2004 and 2005 which we assign to biomass burning. The limited WFM-DOAS data set, covering only the years 2004 and 2005, does not allow further conclusions about the agreement with the FTIR observations being highly influenced by biomass burning during these periods.

The biomass burning enhancements cannot be seen in the SCIAMACHY XVMR observations because of the large footprint of the SCIAMACHY retrievals and the retrieval method itself: column averaged volume mixing ratios are derived from the measured ratio $\mathrm{CH}_{4} / \mathrm{CO}_{2}$. Methane enhancements due to biomass burning are hidden in the $\mathrm{CH}_{4} / \mathrm{CO}_{2}$ ratio as both species are enhanced in a similar way given typical emission factors. The good agreement of the $\mathrm{CH}_{4} / \mathrm{CO}_{2}$ ratio of FTIR and satellite, and the differences between FTIR and satellite $\mathrm{XVMR}\left(\mathrm{CH}_{4}\right)$ shows that the influence of biomass burning for methane can hardly be detected by the satellite (with this retrieval method). The consistency of the FTIR and the satellite observations of the $\mathrm{CH}_{4} / \mathrm{CO}_{2}$ ratio suggests that biomass burning might be the cause for the dif- ferences observed between the FTIR and the SCIAMACHY $\mathrm{XVMR}\left(\mathrm{CH}_{4}\right)$. Since the FTIR measurements are restricted to the dry seasons, no firm conclusions can be drawn regarding the differences in the seasonality between the two different SCIAMACHY products. These FTIR measurements represent the first ground-based validation of the methane retrievals from SCIAMACHY spectra in the inner tropics.

\section{Supplementary material related to this article is available online at: http://www.atmos-chem-phys.net/10/7231/2010/ acp-10-7231-2010-supplement.pdf.}

Acknowledgements. We kindly acknowledge Ed Dlugokencky and the NOAA ESRL network for providing the surface in situ data for Ascension Island and Ragged Point, Barbados. We wish to thank Cor Becker and his team of the Meteorological Service of Suriname for their support and cooperation, and Dennis Wip and Bing Tan from the Anton-de-Kom-University for their support of the measurement campaigns. We also thank Martine de Mazière (Belgian Institute for Space Aeronomy) for organisation and support. We acknowledge Christian Rödenbeck for providing the TM3 model data. Financial support by the Zentrale Forschungsförderung (ZF) of the University Bremen and by the EU within STAR, SCOUT, HYMN and ACCENT is acknowledged.

Edited by: R. Holzinger

\section{References}

Andreae, M. O. and Merlet, P.: Emission of trace gases and aerosols from biomass burning, Global Biogeochem. Сy., 15, 955-966, 2001.

Bergamaschi, P., Krol, M., Dentener, F., Vermeulen, A., Meinhardt, F., Graul, R., Ramonet, M., Peters, W., and Dlugokencky, E. J.: Inverse modelling of national and European $\mathrm{CH}_{4}$ emissions using the atmospheric zoom model TM5, Atmos. Chem. Phys., 5, 2431-2460, doi:10.5194/acp-5-2431-2005, 2005.

Bergamaschi, P., Frankenberg, C., Meirink, J., Krol, M., Dentener, F., Wagner, T., Platt, U., Kaplan, J., Körner, S., Heimann, M., and Goede, A.: Satellite cartography of atmospheric methane from SCIAMACHY on board ENVISAT: II. Evaluation based on inverse model simulations, J. Geophys. Res., 112, D02304, doi:10.1029/2006JD007268, 2007.

Bergamaschi, P., Frankenberg, C., Meirink, J. F., Krol, M., Villani, M. G., Houweling, S., Dentener, F., Dlugokencky, E. J., Miller, J. B., Gatti, L., Engel, A., and Levin, I.: Inverse modeling of global and regional $\mathrm{CH} 4$ emissions using SCIAMACHY satellite retrievals, J. Geophys. Res., 114, D22301, doi:10.1029/ 2009JD01228, 2009.

Buchwitz, M., de Beek, R., Noël, S., Burrows, J. P., Bovensmann, H., Schneising, O., Khlystova, I., Bruns, M., Bremer, H., Bergamaschi, P., Krner, S., and Heimann, M.: Atmospheric carbon gases retrieved from SCIAMACHY by WFM-DOAS: version $0.5 \mathrm{CO}$ and $\mathrm{CH}_{4}$ and impact of calibration improvements on $\mathrm{CO}_{2}$ retrieval, Atmos. Chem. Phys., 6, 2727-2751, doi:10.5194/acp6-2727-2006, 2006. 
Dlugokencky, E. J., Steele, L. P., Lang, P. M., and Masarie, K. A.: The growth rate and distribution of atmospheric methane, J. Geophys. Res., 99, 17021-17043, 1994.

Dlugokencky, E. J., Houweling, S., Bruhwiler, L., Masarie, K. A., Lang, P. M., Miller, J. B., and Tans, P. P.: Atmospheric methane levels off: Temporary pause or a new steady state?, Geophys. Res. Lett., 30(19), doi:10.1029/2003GL018126, 2003.

Dlugokencky, E. J., Bruhwiler, L., White, J. W. C., et al.: Observational constraints on recent increases in the atmospheric $\mathrm{CH}_{4}$ burden, Geophys. Res. Lett., 36, L18803, doi:10.1029/ 2009GL039780, 2009a.

Dlugokencky, E. J., Lang, P. M., and Masarie, K. A.: Atmospheric Methane Dry Air Mole Fractions from the NOAA ESRL Carbon Cycle Cooperative Global Air Sampling Network, 19832008, Version: 2009-06-18, Path: ftp://ftp.cmdl.noaa.gov/ccg/ ch4/flask/event/, 2009b.

Dueck, T. A., de Visser, R., Poorter, H., Persijn, S., Gorissen, A., de Visser, W., Schapendonk, A., Verhagen, J., Snel, J., Harren, F. J. M., Ngai, A. K. Y., Verstappen, F., Bouwmeester, H., Voesenek, L. A. C. J., and van der Werf, A.: No evidence for substantial aerobic methane emission by terrestrial plants: A 13C-labelling approach, New Phytol., 175, 29-35, doi:10.1111/j.1469-8137.2007.02103.x, 2007.

Forster, P., Ramaswamy, V., Artaxo, P., Berntsen, T., Betts, R., Fahey, D., Haywood, J., Lean, J., Lowe, D., Myhre, G., Nganga, J., R. Prinn, G. Raga, M. S., and Dorland, R. V.: Changes in Atmospheric Constituents and in Radiative Forcing, Climate Change 2007: The Physical Science Basis. Contribution of Working Group I to the Fourth Assessment Report of the Intergovernmental Panel on Climate Change (IPCC), 2007.

Fortuin, J., Becker, C., Fujiwara, M., Immler, F., Kelder, H. M., Scheele, M. P., Schrems, O., , and Verver, G. H. L.: Origin and transport of tropical cirrus clouds observed over Paramaribo, Suriname $\left(5.8^{\circ} \mathrm{N}, 55.2^{\circ} \mathrm{W}\right)$, J. Geophys. Res., 112, D09107, doi: 10.1029/2005JD006420, 2007.

Frankenberg, C., Meirink, J. F., van Weele, M., Platt, U., and Wagner, T.: Assessing Methane Emissions from Global Space-Borne Observations, Science, 308, 1010-1014, doi:10. 1126/science.1106644, http://www.sciencemag.org/cgi/content/ abstract/308/5724/1010, 2005.

Frankenberg, C., Meirink, J. F., Bergamaschi, P., Goede, A. P. H., Heimann, M., Körner, S., Platt, U., van Weele, M., and Wagner, T.: Satellite chartography of atmospheric methane from SCIAMACHY on board ENVISAT: Analysis of the years 2003 and 2004, J. Geophys. Res., 111, D07303, doi:10.1029/ 2005JD006235, 2006.

Frankenberg, C., Bergamaschi, P., Butz, A., Houweling, S., Meirink, J.-F., Notholt, J., Petersen, A. K., Schrijver, H., Warneke, T., and Aben, I.: Tropical methane emissions: A revised view from SCIAMACHY onboard ENVISAT, Geophys. Res. Lett., 35, L15811, doi:10.1029/2008GL034300, 2008a.

Frankenberg, C., Warneke, T., Butz, A., Aben, I., Hase, F., Spietz, P., and Brown, L. R.: Pressure broadening in the $2 \mathrm{v} 3$ band of methane and its implication on atmospheric retrievals, Atmos. Chem. Phys., 8, 5061-5075, doi:10.5194/acp-8-5061-2008, 2008b.

Houweling, S., Röckmann, T., Aben, I., Keppler, F., Krol, M., Meirink, J. F., Dlugokencky, E. J., and Frankenberg, C.: Atmospheric constraints on global emissions of methane from plants,
Geophys. Res. Lett., 33, L15821, doi:10.1029/2006GL026162, 2006.

Keppler, F., Hamilton, J. T. G., Braß, M., and Röckmann, T.: Methane emissions from terrestrial plants under aerobic conditions, Nature, 439, 187-191, doi:10.1038/nature04420, http: //dx.doi.org/10.1038/nature04420, 2006.

Kirschbaum, M. U. F. and Walcroft, A.: No detectable aerobic methane efflux from plant material, nor from adsorption/desorption processes, Biogeosciences, 5, 1551-1558, doi:10.5194/bg-5-1551-2008, 2008.

Meirink, J., Bergamaschi, P., Frankenberg, C., d'Amelio, M., Dlugokencky, E., Gatti, L., Houweling, S., Miller, J., Röckmann, T., Villani, M., and Krol, M.: Four-dimensional variational data assimilation for inverse modeling of atmospheric methane emissions: Analysis of SCIAMACHY observations, J. Geophys. Res., 113, D17301, doi:10.1029/2007JD009740, 2008 a.

Meirink, J. F., Bergamaschi, P., and Krol, M. C.: Fourdimensional variational data assimilation for inverse modelling of atmospheric methane emissions: method and comparison with synthesis inversion, Atmos. Chem. Phys., 8, 6341-6353, doi:10.5194/acp-8-6341-2008, 2008b.

Miller, J., Gatti, L., d'Amelio, M., Crotwell, A., Dlugokencky, E., Bakwin, P., Artaxo, P., and Tans, P.: Airborne measurements indicate large methane emissions from the eastern Amazon basin, Geophys. Res. Lett., 34, L10809, doi:10.1029/2006GL029213, 2007.

Nisbet, R., Fisher, R., Nimmo, R., Bendall, D., P.M, C., GallegoSala, A., Hornibrook, E., López-Juez, E., Lowry, D., Nisbet, P., Shuckburgh, E., Sriskantharajah, S., Howe, C. J., and Nisbet, E. G.: Emission of methane from plants, Proc. R. Soc., 276, 1347-1354, doi:10.1098/rspb.2008.1731, 2009.

Petersen, A. K., Warneke, T., Lawrence, M. G., Notholt, J., and Schrems, O.: First ground-based FTIR observations of the seasonal variation of carbon monoxide in the tropics, Geophys. Res. Lett., 35, L03813, doi:10.1029/2007GL031393, 2008.

Rigby, M., Prinn, R. G., Fraser, P. J., Simmonds, P. G., Langenfelds, R. L., Huang, J., Cunnold, D. M., Steele, L. P., Krummel, P. B., Weiss, R. F., O'Doherty, S., Salameh, P. K., Wang, H. J., Harth, C. M., Mühle, J., and Porter, L. W.: Renewed growth of atmospheric methane, J. Geophys. Res., 35, L22805, doi:10.1029/2008GL036037, 2008 .

Rinsland, C. P., Goldman, A., Murcray, F. J., Murcray, F. H., Blatherwick R. D., and Murcray, D. G.: Infrared Measurements of Atmospheric Gases Above Mauna Loa, Hawaii, in February 1987, J. Geophys. Res., 93(D10), 12607-12626, doi:10.1029/JD093iD10p12607, 1988.

Rinsland, C. P., Jones, N. B., Connor, B. J., Logan, J. A., Pougatchev, N. S., Goldman, A., Murcray, F. J., Stephen, T. M., Pine, A. S., Zander, R., Mahieu, E., and Demoulin, P.: Northern and Southern hemisphere ground-based infrared spectroscopic measurements of tropospheric carbon monoxide and ethane, J. Geophys. Res., 103, 28197-28217, 1998.

Rödenbeck, C.: Estimating $\mathrm{CO}_{2}$ sources and sinks from atmospheric mixing ratio measurements using a global inversion of atmospheric transport, Tech. Rep. 6, Max Planck Institute for Biogeochemistry, 2005.

Schneising, O., Buchwitz, M., Burrows, J. P., Bovensmann, H., Bergamaschi, P., and Peters, W.: Three years of greenhouse gas column-averaged dry air mole fractions retrieved from satel- 
lite - Part 2: Methane, Atmos. Chem. Phys., 9, 443-465, doi:10.5194/acp-9-443-2009, 2009.

Senten, C., De Mazière, M., Dils, B., Hermans, C., Kruglanski, M., Neefs, E., Scolas, F., Vandaele, A. C., Vanhaelewyn, G., Vigouroux, C., Carleer, M., Coheur, P. F., Fally, S., Barret, B., Baray, J. L., Delmas, R., Leveau, J., Metzger, J. M., Mahieu, E., Boone, C., Walker, K. A., Bernath, P. F., and Strong, K.: Technical Note: New ground-based FTIR measurements at Ile de La Runion: observations, error analysis, and comparisons with independent data, Atmos. Chem. Phys., 8, 3483-3508, doi:10.5194/acp-8-3483-2008, 2008.
Wang, Z.-P., Han, X.-G., Wang, G. G., Song, Y., and Gulledge, J.: Aerobic methane emission from plants in the inner Mongolia steppe, Environ. Sci. Technol., 42(1), 62-68, 2008.

Warneke, T., Meirink, J. F., Bergamaschi, P., Grooß, J. U., Notholt, J., Toon, G. C., Velazco, V., Goede, A. P. H., and Schrems, O.: Seasonal and latitudinal variation of atmospheric methane: A ground-based and ship-borne solar IR spectroscopic study, Geophys. Res. Lett., 33, L14812, doi:10.1029/2006GL025874, 2006.

Washenfelder, R. A., Wennberg, P. O., and Toon, G. C.: Tropospheric methane retrieved from ground-based near-IR solar absorption spectra, Geophys. Res. Lett., 30, 2226, doi:10.1029/ 2003GL017969, 2003. 